\title{
DOMINAÇÃO E SUBORDINAÇÃO NAS RELAÇÕES TRABALHO NOS CANAVIAIS DE ITUIUTABA, MINAS GERAIS, BRASIL
}

\author{
DOMINATION AND SUBORDINATION IN WORK \\ RELATIONSHIPS IN THE SUITES OF ITUIUTABA, MINAS \\ GERAIS, BRAZIL
}

\begin{abstract}
Daniel Féo Castro de Araújo
Doutorando pelo Programa de Pós-Graduação em Geografia da Universidade de Brasília (UnB) daniel.feo@gmail.com

Fernando Luiz Araújo Sobrinho

Professor do Programa de Pós-Graduação em Geografia, Departamento de Geografia da Universidade de Brasília (UnB)

lasobrinho@gmail.com
\end{abstract}

\begin{abstract}
Resumo
O artigo tem como objetivo caracterizar o perfil dos trabalhadores envolvidos na cultura agrícola da cana-de-açúcar e investigar as suas condições de trabalho no corte da cana na microrregião de Ituiutaba, MG. O recorte territorial justifica-se pelo fato da microrregião de Ituiutaba enfrentar nas últimas décadas um intenso movimento modernizador de seus territórios rurais por conta dos investimentos do agroindústria canavieiro direcionado à produção de commodities agrícolas para exportação, pautado na superexploração da força de trabalho e dos recursos naturais. A metodologia utilizada para desenvolvimento da pesquisa parte da revisão bibliográfica para o entendimento da dinâmica do fenômeno a ser estudado e, também, para construção de referencial teórico. Outra etapa da metodologia refere-se ao levantamento de dados de fonte primária, feito através da realização de trabalho de campo cujo objetivo foi identificar os sujeitos sociais envolvidos no corte da cana. Nesse momento, pautamos em entrevistas junto aos trabalhadores migrantes, principalmente, nos finais de semanas e feriados, onde os mesmos tinham tempo livre para participação nas entrevistas. Destaca-se que as entrevistas bem como a identificação dos sujeitos e o uso de suas falas foi autorizado através de assinatura de termo de consentimento. Consideramos que, através dos dados obtidos, os trabalhadores, em sua maioria migrantes, para serem contratados são avaliados segundo sua capacidade de produção, sua resistência física e sua subordinação aos superiores. $\mathrm{O}$ salário por produção implica a superexploração da força de trabalho que repercute nas condições laborais e de saúde dos trabalhadores, bem como, em relações de trabalho nem sempre de longa duração e que reforçam estereótipos locais e as migrações sazonais no Brasil.
\end{abstract}

Palavras-chave: Migração Sazonal. Precarização do Trabalho. Justiça Social. Complexo sucroenergético. Trabalhadores. 


\begin{abstract}
The article aims to characterize the profile of workers involved in the sugarcane agricultural culture and to investigate their working conditions in the cutting of sugarcane in the micro-region of Ituiutaba, MG. The territorial cut is justified by the fact that the micro-region of Ituiutaba faced in the last decades an intense modernizing movement of its rural territories due to the investments of the sugarcane agribusiness directed to the production of agricultural commodities for export, based on the overexploitation of the workforce and natural resources. The methodology used for the development of the research starts from the bibliographic review to understand the dynamics of the phenomenon to be studied, and also to construct a theoretical framework. Another stage of the methodology refers to the collection of data from primary sources, which was done through field work whose objective was to identify the social subjects involved in the cutting of sugarcane. At that moment, we asked about periods when the migrant workers had free time to participate in the interviews, with priority for holidays and weekends. It is noteworthy that signatures on a consent form authorized the interviews as well as the identification of the subjects and the use of their speeches. We consider that, through the data obtained, workers, mostly migrants, to be hired are evaluated according to their production capacity, their physical resistance and their subordination to superiors. The production wage implies overexploitation of the workforce, which has an impact on workers' health and working conditions, as well as on not always long-term work relationships that reinforce local stereotypes and seasonal migrations in Brazil.
\end{abstract}

Keywords: Seasonal Migration. Precarious Work. Social justice. Sugar-energy complex. Workers.

\title{
Introdução
}

Os debates sobre migração na conjuntura da precarização do trabalho fazem jus a atenção, principalmente, uma vez que pode ser avaliada como um elemento da exploração dos trabalhadores, (SILVA,1999; PEREIRA, 2010), em grande parte das ocorrências, considerando-se que a migração é de uma maneira geral coagida pelas más condições de vida no local de origem, o que colabora para que os migrantes se submetam a contratações irregulares e ilegais (PALHARES, 2014). Ademais, os trabalhadores são iludidos em relação às condições de trabalho e salários que vão encontrar nos locais para onde migram. Assim, percebeu-se que o preconceito e a discriminação marcaram as relações culturais vivenciadas na cidade de Ituiutaba, onde trabalhadores migrantes e mineiros tijucanos estão inseridos, pois os costumes, o modo de vida, enfim a identidade desses trabalhadores foi tida como distinta e inferior. 
A microrregião geográfica de Ituiutaba localiza-se na Mesorregião do Triângulo Mineiro/Alto Paranaíba como pode ser observado na figura 1 e transformou-se numa das principais regiões produtoras de cana-de-açúcar do estado de Minas Gerais, constituindo uma área plantada com cana-de-açúcar aumentou de 14.135 hectares no ano 2005 para 68.667 hectares no ano de 2010 e 87.544 hectares em 2014, segundo o Instituto Brasileiro de Geografia e Estatística (IBGE). Esta expansão canavieira colaborou até o ano de 2013, para que existisse um número expressivo de trabalhadores migrantes executando o corte manual da cana na região. Estes ganhavam por produtividade, o que instigava uma maior produção, isto é, sistemas de gratificação aqueles que produzem mais.

Mapa 01: Localização do Município de Ituiutaba/MG

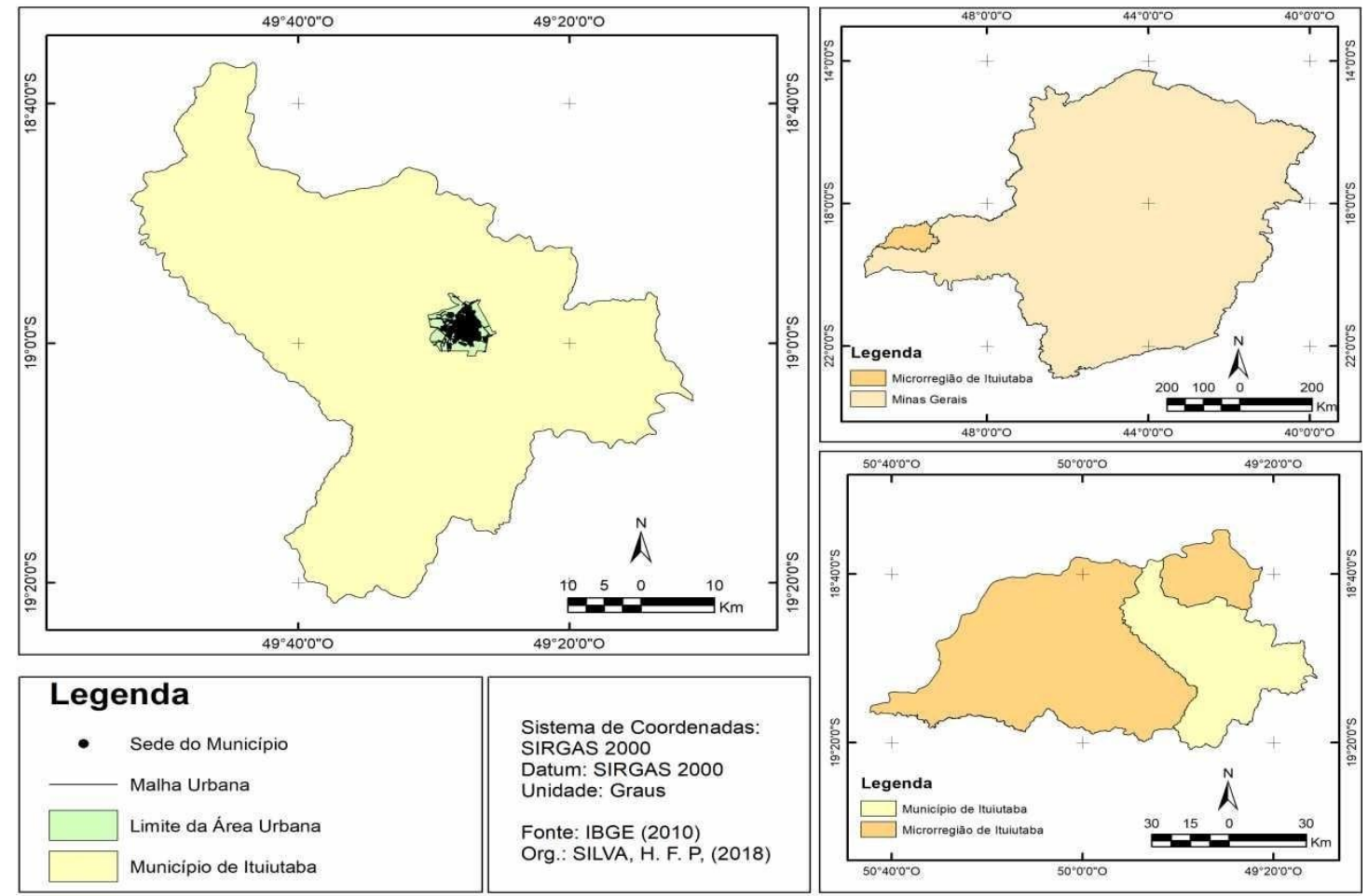

Lamentavelmente esses trabalhadores mantinham falsas esperanças de que recebendo uma maior quantia de dinheiro terão melhores condições de vida, ainda que para isso necessitem cortar mais de 12 toneladas de cana ao dia. Contudo, desde o ano de 2014, não existe o corte manual da cana de açúcar na microrregião geográfica de Ituiutaba, já que indústrias como as do Grupo João Lyra assumiram falência e interromperam suas atividades, outras como a BP (British Petroleum) concordaram com o corte da cana $100 \%$ mecanizado a fim de ampliar a produção. 
Destacamos que falar das relações de trabalho e do trabalhador envolvido no corte de cana, no Pontal do Triangulo Mineiro, Minas Gerais, se faz imprescindível, pois, compreendemos que a construção desses sujeitos sociais se constitui em um dos pilares do processo de modernização da agricultura e da inclusão do setor sucroenergético na região. A inserção de novas técnicas introduzidas pelo processo de modernização da agricultura, não só devem ser percebidas a partir do emprego de insumos e maquinários, como também pelas mudanças nas relações de trabalho (CARVALHO, SANTOS, SILVA, 2013; ARAÚJO, 2018).

O setor sucroenergético, no que se refere às mesorregiões do Triangulo Mineiro e Alto Paranaíba, é a atividade agrícola que mais demonstra ser condutor da modernização do campo (NERY, SANTOS 2016). Os pequenos produtores foram em grande medida, desterritorializados, dando lugar às empresas capitalistas, que passaram a empregar mão de obra assalariada (MATTOS, 2011). Assim, a modernização da agricultura brasileira levou a redução da reprodução das pequenas propriedades ao mesmo tempo em que ampliou as perspectivas para a formação da classe proletária no campo (CARVALHO, 2010).

Isso é reflexo do cultivo da cana-de-açúcar no território brasileiro que perpassa pelo novo ciclo de expansão, se evidenciando no desenvolvimento da agroindústria brasileira e tem ganhado atenção internacional devido à possibilidade de se tornar fonte de matriz energética alternativa (ELIAS, 2006; BERNARDES, 2015). Dito isso, o etanol produzido a partir da cana-de-açúcar é empregado como combustível automotivo no Brasil desde a década de 1970, (FREDERICO, 2013), e, atualmente o Brasil voltou a ser um grande consumidor de álcool combustível, devido à adoção da tecnologia flexfuel nos motores dos automóveis, que permite a mistura de gasolina e álcool em qualquer proporção, além da geração de energia termoelétrica a partir da utilização do bagaço de cana para queima e geração de energia. O crescimento tanto da área de produção, do número de trabalhadores envolvidos neste setor, quanto à ampliação da produção de açúcar, álcool e derivados são efeitos de uma política delineada para a valorização da cana-de-açúcar enquanto cultura agrícola para o Brasil (CASTILLO, 2005; FREDERICO, 2013). Tal conjuntura consente adotar um novo ajuste na economia política da agroindústria canavieira, apoiado pelo Estado e com claro fortalecimento de agentes externos, agora inclusive ancorados em investimentos próprios de um capital 
financeiro que procura novas estratégias de remuneração no país, implicando no desenvolvimento das exportações de commodities e no fortalecimento da condição subordinada do Brasil na divisão internacional do trabalho (PEREIRA, 2016; CARVALHO, 2018).

Além da expansão da área de cultivo, a agroindústria canavieira passou por mudanças no processo produtivo que resultaram no incremento da mecanização da produção, em especial a colheita/corte da cana, em significativo aumento de produtividade, no aumento da competitividade e na melhoria e qualidade dos produtos, mudanças que são integrantes da reestruturação tecnológica do capital setor sucroenergético, (CLEPS JR., 2009; THOMAZ JR., 2010; CAMELINI, 2011; ELIAS, 2011; ARAÚJO, 2019). Entretanto, essas mudanças ainda estão ligadas à extinção de postos de trabalho, a maior precarização das relações e condições de trabalho, à intensificação do trabalho e no avanço do desgaste físico e mental dos trabalhadores.

Na década de 1950 cada trabalhador cortava, em média, três toneladas de cana/dia, na década de 1980, este número chega a cerca de seis toneladas/dia e, ao final da década 1990 e início da década de 2000 a média exigida do trabalhador alcança as doze toneladas/dia (SILVA, 1999; ALVES, 2006).

Segundo Palhares (2014), ainda persistem as condições de precarização do trabalho na colheita manual da cana-de-açúcar sendo que aumentou o esforço despendido pelos cortadores nos últimos 30 anos. É nesse sentido que está se compreendendo a região do Triângulo Mineiro, pois a formação do assalariado rural temporário, está ligado ao processo produtivo intimamente atrelado a produção sucessiva da mais-valia e em consequência, com as demais transformações vividas no processo de proletarização e precarização.

As condições de habitação a que esses trabalhadores se submetem é outro agravante para suas já precárias condições de vida. Isso ocorre, entre outras coisas, pelo fato de grande parte deles ser composto por migrantes que não têm outra possibilidade de moradia (SILVA, 2007).

Partimos do pressuposto que nem todo trabalhador consegue realizar o corte da cana-de-açúcar, à medida que esta atividade requer grande dispêndio de força física. Além disso, estes trabalhadores ao migrarem em busca de trabalho estão sujeitos, muitas vezes, 
às condições extremamente precárias de moradia, alimentação e saúde, entre outras formas e situações de exploração e subjugação.

$\mathrm{O}$ artigo tem por objetivo caracterizar o perfil dos trabalhadores envolvidos nesta atividade e investigar as suas condições de trabalho no corte da cana-de-açúcar na microrregião de Ituiutaba, MG. A proposta justifica-se pelo fato de a microrregião de Ituiutaba enfrentar nas últimas décadas intenso movimento de modernização de seus territórios rurais por conta dos investimentos do agroindústria canavieiro focado na produção de commodities agrícolas para exportação, pautado na superexploração da força de trabalho e dos recursos naturais.

$\mathrm{Na}$ perspectiva de adensar as reflexões aqui produzidas, utilizamos de algumas observações de campo realizadas, em acompanhamento a um grupo de trabalhadores sazonais contratados temporariamente pela usina Triálcool.

Desde a contratação dos trabalhadores migrantes, as duas Usinas - a Triálcool e a Vale do Paranaíba - pertencentes ao grupo empresarial nordestino João Lyra disponibilizaram aos trabalhadores moradias em alojamentos ${ }^{1}$. No período de 2009 a 2013, havia quatro alojamentos e três se localizavam nas proximidades do centro da cidade e um no setor sul. A inserção da pesquisa de campo aconteceu no "Alojamento Horizonte", antigo prédio da polícia civil de Ituiutaba, MG. Ali residiam 50 trabalhadores, organizados numa turma ${ }^{2}$ denominada de "Turma Alagoas". Na Usina Triálcool, as turmas são denominadas de acordo com o estado de origem dos trabalhadores migrantes.

Em razão das fiscalizações dos órgãos públicos (MPF - Ministério Público Federal, MTE - Ministério do Trabalho e Emprego, MPT - Ministério Público do Trabalho) para combater as práticas ilícitas de condições degradantes do trabalho nos canaviais, a presença de estranhos não é bem-vinda, por parte da usina. Compartilhar as condições de vida existentes nos alojamentos pode custar caro, caso seja detectado condições degradantes, a usina ou o fornecedor podem ser autuados como infratores por condições de trabalho análogas à escravidão. Isso implica, para a usina, em pagar onerosas multas e ter o nome da empresa divulgado na temida "lista suja do trabalho escravo". Entre as implicações negativas de uma empresa ter nome incluído nesta lista é a de não ficar apta a receber financiamentos público-estatais, e ainda ter a imagem

\footnotetext{
${ }^{1}$ Alojamento é o local destinado ao repouso dos trabalhadores.

${ }^{2}$ Grupo de trabalhadores que operam juntos sob a direção de um chefe.
} 
prejudicada pelo estigma de "empresa escravagista", impedimentos às exportações de açúcar e álcool para outros países.

Os quatros alojamentos mantidos pelo grupo João Lyra à época em Ituiutaba eram fechados para visitas, sendo comum ter uma placa com letras grandes emitindo a mensagem: "Proibida entrada de estranhos". A justificativa de proteger os trabalhadores dos "estranhos" pode ser lida ainda como uma iniciativa de isolá-los do contato com algo ou alguém que venha comunicar e dar visibilidade as suas condições de vida.

$\mathrm{O}$ primeiro contato com os alojamentos partiu de um projeto em conjunto com a Pastoral do Migrante ${ }^{3}$. O Projeto teve como objetivo realizar rodas de conversa para sensibilizar sobre os riscos, consequências e os impactos na saúde decorrente do trabalho no canavial.

A interação com os trabalhadores foi construída aos poucos, as visitas aos alojamentos aconteciam nos finais de semana. $\mathrm{O}$ fato de ter chegado ao alojamento com um agente da pastoral gerou maior confiança nos trabalhadores. A acolhida gradual constituída através de apresentação de documentários e filmes retratavam suas histórias de vida. Após assistirmos aos documentários ou filmes abríamos uma roda de conversa para dialogar sobre o assunto. Ao passar dos dias, diminuíam as desconfianças e aumentavam as possibilidades de diálogos.

Assim, nos organizamos a partir das rodas de conversa e propomos aos trabalhadores maior participação e acompanhamento nas rotinas dos trabalhadores, e os mesmos não se recusou a participar da pesquisa.

Durante a realização da pesquisa, utilizamos um roteiro de entrevista semiestruturada, o qual possuía perguntas abertas e fechadas, relacionadas às características do trabalhador e às peculiaridades do seu trabalho. Além disso, foram realizadas várias conversas informais com os cortadores de cana, e utilizados instrumentos de registros como, diário de campo para anotações, filmadora e máquina fotográfica.

\footnotetext{
${ }^{3}$ Pastoral do Migrante é uma entidade de católicos brasileiros. De acordo com seu site oficial: "A Pastoral do Migrante é um serviço eclesial voltado para a acolhida, orientação e inserção socio-religiosa dos migrantes sob a animação das Congregações dos Missionários e Missionárias Escalabrinianos, que atuam no Brasil em estreito vínculo com o Setor de Mobilidade Humana da Comissão Episcopal para o Serviço da Caridade, da Justiça e da Paz, da CNBB (Conferência Nacional dos Bispos do Brasil) e com o Serviço Pastoral dos Migrantes". Disponível na internet em <http://www.mscs.org.br/Noticias.aspx?id=63>. Acesso em 17/05/2018.
} 
O artigo apresentado é fruto de reflexões que foram desenvolvidas na produção do documentário "Nas trilhas da cana" e na pesquisa de iniciação científica intitulada "A expansão da cana-de-açúcar e a precarização das relações de trabalho na Microrregião Geográfica de Ituiutaba/MG" por meio do Grupo de Estudos e Pesquisas Agrárias e Trabalho (GEPEAT), do curso de Geografia , do Instituto de Ciências Humanas do Pontal (ICHPO), da Universidade Federal de Uberlândia, em Ituiutaba/MG com apoio financeiro da Fundação de Amparo à Pesquisa do Estado de Minas Gerais (FAPEMIG).

\section{A Precariedade das condições de trabalho no eito ${ }^{5}$ da cana}

Fomos para o "Alojamento Horizonte", antigo prédio da polícia civil de Ituiutaba, onde havia 50 trabalhadores, era por volta das quatro e trinta da madrugada quando chegamos ao alojamento para acompanhá-los em seu dia de trabalho. O ônibus da empreiteira é um antigo carro de linha da frota urbana de transporte da cidade e possui cerca de quarenta e cinco lugares. Tem rádio toca fitas e as poltronas não são revestidas com espuma. O ônibus ainda não havia estacionado, mas alguns trabalhadores se encontravam em frente ao alojamento, ponto de referência para o embarque da turma.

Assim que chegou o ônibus, esperamos todos os trabalhadores adentrarem no transporte para logo em seguida entrarmos. Verificamos se o ônibus estava completo e os primeiros trabalhadores ao embarcarem não se sentiram incomodados, ou curiosos com a nossa presença, pois muitos destes sabiam a uma semana que estaríamos viajando com os trabalhadores para acompanhá-los em um dia de trabalho.

Em nosso percurso rumo ao talhão ${ }^{6}$, previa-se a fim de completar o grupo de trabalhadores, antes de chegarmos à usina, a passagem por algumas ruas da vila e também

\footnotetext{
${ }^{4} \mathrm{O}$ documentário retrata as condições de trabalho a que são submetidos os trabalhadores empregados nas agroindústrias canavieiras da região de Ituiutaba, especialmente os cortadores de cana, migrantes nordestinos. Disponível em <https://www.youtube.com/watch?v=UX3Pw5F5TMM\&ab_channel=GustavoMendes $>$. Acessado 25 de jan 2021.

${ }^{5} \mathrm{O}$ corte da cana se dá em um retângulo, com 8,5 metros de largura, equivalente a 5 "ruas" (linhas em que é plantada a cana) e um comprimento que varia conforme a produtividade do trabalhador. Este retângulo é chamado eito; a distância medida ao final do dia indica o ganho diário do trabalhador. Os metros lineares de cana, multiplicados pelo valor da cana pesada na usina, dão o valor da diária a receber.

${ }^{6}$ Um canavial é dividido em talhões e cada talhão é composto por várias linhas de canas plantadas de forma paralela. Talhão é, portanto, a designação dada a uma área cultivada; não tem uma medida específica, tanto pode medir 2 como 20 hectares. O espaçamento entre as linhas, formando as ruas, varia conforme a topografia, a área, o tipo de solo, a variedade de cana etc, mas em geral, se mantém uniforme em cada
} 
pelos bairros Bela Vista e Ipiranga, localizados na área leste do município, caminho de acesso à usina na BR $365^{7}$. Bem próximo dali estava a Paróquia São Francisco de Assis, pertence à Diocese de Ituiutaba, MG. Ao passarmos em frente a sua fachada, podemos observar o ato de se retirar bonés e chapéus e de se fazer o sinal da cruz em reverência à Igreja antes da chegada ao talhão, esta cena nos pareceu ser um ritual de identificação religiosa e de pedidos, quem sabe, de proteção entre os passageiros.

Tão logo isto foi realizado, os olhares curiosos dos trabalhadores voltavam para nós, querendo saber se compartilhávamos da mesma representação. Em seu percurso, ao tomar a direção da rodovia, em uma das avenidas, o ônibus fez uma pequena parada na mercearia para tomar café, onde todos do ônibus costumam se encontrar. Novo grupo de trabalhadores desceu, e após o café, novamente embarcaram. O volume das falas no coletivo era alto e o rádio contribuía para esta situação, encontrando-se sintonizado em uma frequência que executava composições sertanejas, sambas e outras variedades musicais.

Algumas janelas do ônibus estavam fechadas, mas alguns fumavam despreocupadamente. Muitos trabalhadores faziam as primeiras refeições de modo comunitário dentro do ônibus: tomava-se café, comiam-se pães e bolachas; recémadquiridas na mercearia local momento antes.

Após trinta a quarenta minutos, chegamos à usina, mas ninguém desceu do coletivo. Nesta última parada, embarcaram quatro fiscais de campo ${ }^{8}$ e um fiscal geral. ${ }^{9}$ Por isso, antes de entrarmos propriamente na discussão sobre as representações do risco do corte de cana ${ }^{10}$, é necessário descrever o talhão e as condições de trabalho no eito, lançando mão da literatura acadêmica sobre o tema e de anotações do trabalho de campo.

talhão. Estas linhas são agrupadas formando os eitos. Em geral os eitos são compostos por 5 linhas de cana, mas podem existir eitos de 6,7 ou 8 ruas. A extensão de cada eito também varia.

${ }^{7}$ A BR-365 é uma importante rodovia diagonal federal brasileira que liga as regiões Nordeste - Centro Oeste. A BR-365 liga duas cidades importantes de Minas Gerais: Montes Claros - Uberlândia, além de ligar Uberlândia a BR-364 (divisa de Minas Gerais e Goiás), rumo ao Mato Grosso. A rodovia também faz cruzamento com outras rodovias importantes como a BR-040 e a BR-354.

${ }^{8}$ São subordinados diretos dos encarregados. Tem a função de organizar a turma de cortadores para que o trabalho seja executado de acordo com as normas técnicas da usina. Tem poder para punir os trabalhadores. Tem responsabilidade para manter a disciplina nos alojamentos.

${ }^{9}$ São o elo entre os proprietários e os trabalhadores. Supervisionam todas as atividades relacionadas ao corte de cana. Na usina Triálcool são cinco funcionários que fazem esta função. São subordinados apenas aos proprietários.

${ }^{10} \mathrm{O}$ corte manual da cana-de-açúcar é um processo composto por diversas situações de risco à saúde dos trabalhadores, como altas temperaturas, chuvas, presença de poeiras provenientes da terra, da fuligem da cana e de animais peçonhentos e há um risco acentuado de ocorrência de acidentes de trabalho em 
A tarefa dos cortadores de cana é aparentemente simples: munidos de facões devidamente afiados, eles devem cortar a(s) cana(s) com um ou vários golpes dados na sua base ou "pé", despontá-la, isto é, cortar a sua "ponta" superior e carregá-la com os braços até um local preestabelecido, formando montes ${ }^{11}$ ou leiras ${ }^{12}$, para que, numa etapa posterior do processo produtivo, tratores carregadores, as "carregadeiras" ou "guincheiras", a transportem para os caminhões que irão para as usinas, porém tal atividade se revela extremamente extenuante e com riscos de acidentes laborais pelo manuseio de objetos de corte, a acidentes com animais peçonhentos que se encontram nos canaviais, fora a exposição aos fatores climáticos (luz solar intensa, calor, poeira, chuva), e ao ritmo de trabalho intenso e fatigante.

A organização do trabalho no corte de cana é extremamente hierarquizada. Os cortadores estão sempre na mira de um agente da usina, numa intrincada rede de controle. A tarefa dos ficais no processo de produção, conforme pesquisa de campo, a tarefa dos ficais no processo de produção, como viemos verificar depois no talhão - era o de organizar e controlar, especificamente, o trabalho a ser realizado. Para Maria Aparecida Moraes Silva no livro "Errantes do Fim do Século" (1999), o talhão é o espaço que opera o trabalho na usina.

\begin{abstract}
O talhão representa o talho, a parte no conjunto do canavial, laranjal ou cafezal. Fisicamente é a parte delimitada pelos carregadores em que circulam caminhões, tratores etc. Além dessas constatações geográficas, o talhão constitui uma espécie de "departamento de fábrica". O controle da produção, da produtividade da turma do caminhão é feita em cada talhão, em cada departamento do conjunto da unidade produtiva. A administração de tarefas, a divisão do trabalho, bem como divisão sexual do trabalho, a supervisão, enfim, a organização do trabalho, são planejados e controlados em cada talhão. (SILVA, 1999, p. 151).
\end{abstract}

\footnotetext{
decorrência do manuseio do facão, instrumento utilizado para o corte da planta, e do uso inadequado de equipamentos de proteção individuais; além disso, o cortador realiza um conjunto de movimentos corporais que favorecem a adoção de posturas inadequadas e exigem extremo esforço físico. A realização deste conjunto de movimentos bruscos e repetitivos durante a jornada de trabalho e o intenso ritmo de trabalho imposto pelos cortadores, gradativamente, pode determinar o desgaste físico destes indivíduos e o aparecimento de doenças osteomusculares como bursites, tendinites, perda de movimentos em articulações e membros, lesões e incapacidades, além de sintomas como dores musculares e articulares agudas ou crônicas em membros, tórax e na coluna vertebral, cansaço, fadiga, cãibras, cefaléia, desidratação, diarreia, oscilações da pressão arterial e dispneia.

${ }^{11}$ No sistema de montes, os trabalhadores devem carregar a cana cortada até a terceira rua (ou rua do meio) e depositá-la em montes que devem ficar a uma distância aproximada de 2 metros um do outro.

${ }^{12}$ No sistema de leiras, a cana cortada vai sendo depositada também na terceira rua, mas de modo contínuo.
} 
O dispositivo de controle funciona por meio do par vigilância/punição presente no trabalho da cana tem uma correspondência direta com os mecanismos disciplinares de poder analisados pelo filósofo francês Foucault (2010), em sua obra Vigiar e Punir, quando ele observou um novo modo de condução das condutas dos indivíduos que nascia no século XVII na Europa ocidental, de maneira insidiosa, em diversas instituições sociais espraiadas numa rede capilar de poder, nas famílias, fábricas, hospitais, hospícios, escolas, entre outras instituições.

$\mathrm{O}$ trabalhador da cana se sente o tempo todo vigiado por fiscais, sentindo-se assim obrigado a trabalhar mais e melhor. Foucault (2010) se refere ao "Panóptico de Bentham" como um modelo arquitetônico moderno de vigilância/punição. Idealizado para ser aplicado a várias instituições, trata-se de um prédio, constituído de células justapostas umas às outras em formato circular, no centro das quais se situa uma torre de vigilância, da qual apenas um vigilante pode controlar todas as unidades de encarceramento.

$\mathrm{Na}$ utopia disciplinar de Benthan, o processo de disciplinarização dos comportamentos se tornaria tão eficaz e não seria nem mesmo mais necessário à própria existência material do panóptico, pois já se encontraria introjetado em cada indivíduo que se autovigia.

$\mathrm{Na}$ medida em que entravamos no processo do eito, foi possível compreender o espaço de dominação e subordinação, ou seja, a supervisão realizada por meios dos fiscais pode tornar o trabalhador temeroso. Saber se está sendo monitorado indiscutivelmente é uma forma de poder advindo do controle do tempo. "Daí o efeito mais importante do Panóptico: induzir no detento [no trabalhador] um estado consciente e permanente de visibilidade segurador do funcionamento automático do poder. Fazer a vigilância ser permanente em seus efeitos, mesmo se é descontínua em sua ação". Portanto, para Foucault (2010), quanto mais separados estiverem os indivíduos maior será a visibilidade sobre eles. Eliminam-se assim as distrações e as possibilidades de atraso do trabalho.

Nesse sentido Silva (1999) também escreve sobre o eito como espaço de dominação:

\footnotetext{
A leitura do espaço do canavial fornece, numa primeira impressão, a imagem de um mar de cana, um todo homogêneo no qual se distribuem os trabalhadores. Essa visão aparente se desfaz quando se analisa o processo de trabalho como consumo de força de trabalho. Na medida em que se penetra no interior do laboratório secreto do eito, das relações de produção, descortina-se um universo submerso, pilar básico da estrutura de dominação (SILVA,1999, p. 151).
} 
Ao refletir sobre o assunto, ainda próximo do ônibus, observávamos os eitos sendo distribuídos, mas não ouvíamos nenhum tipo de manifestação contrária, tudo era silêncio. $\mathrm{Na}$ foto (1), podemos observar os trabalhadores sentados no entorno do ônibus arrumando as ferramentas de trabalho para colheita do dia.

Foto 1: Trabalhador na Usina Laginha Agroindustrial S/A- Unidade Trialcool

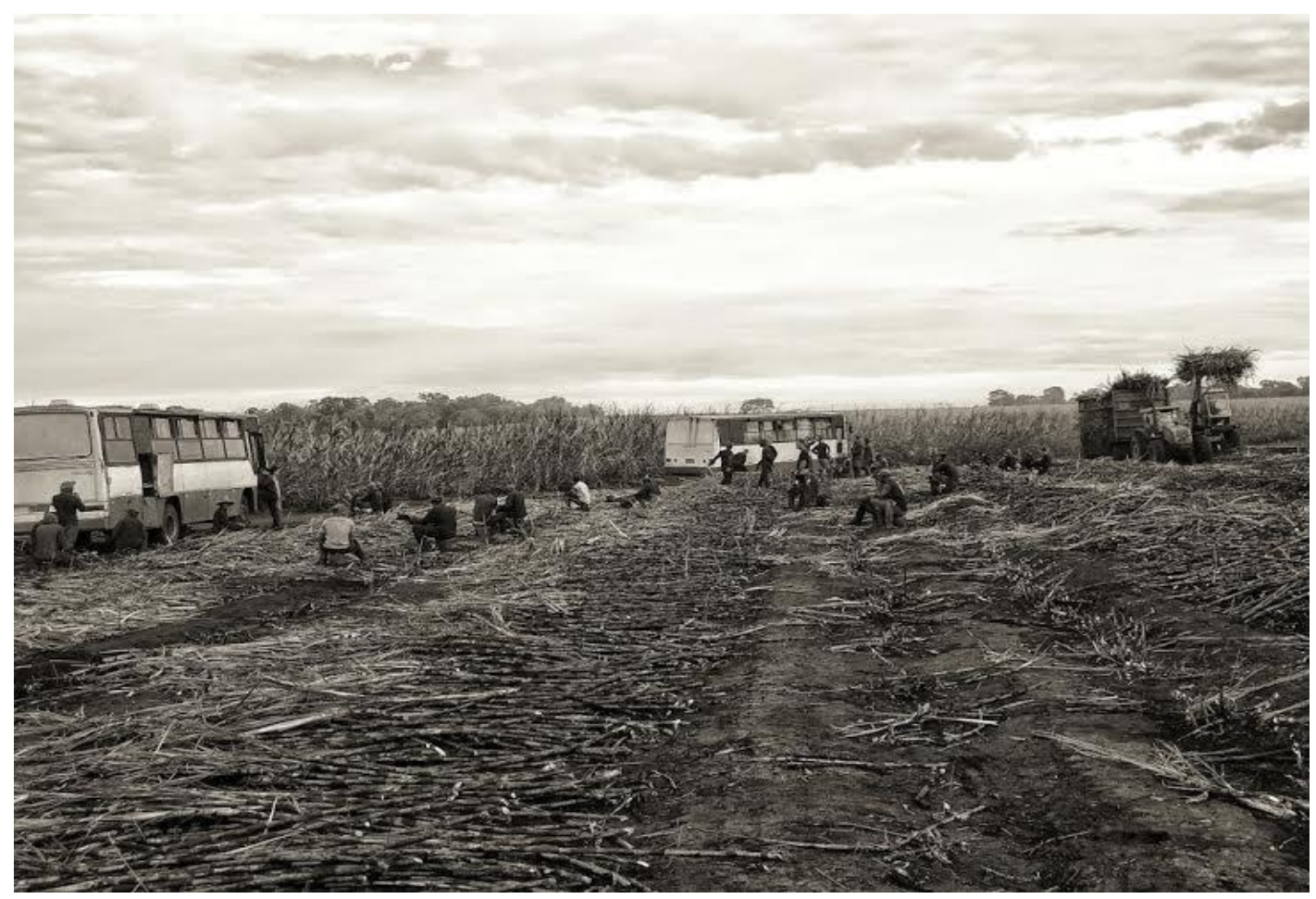

Autor: ARAÚJO, D. F. C. (2012).

Cada trabalhador vai então receber o seu eito para cortar.

A hora em que ele [o fiscal] está escalando o eito, a gente vai atrás: aqui Maria, José, João[...].Ele vai deixando e você vai ficando ali (João).

O fiscal marca o número da pessoa e o número do eito designado. E este controle servirá para saber o quanto cada trabalhador cortou por dia, e determinar o seu pagamento.

O fiscal fica assim como [...] um exemplo, um professor numa sala de aula. Ele manda lá. Ele dá o eito. Terminou aquele eito, ele dá outro, ele olha pra ver se o serviço está certo, se você não deixou toco, se você cortou bem as pontas [....]. (Paulo).

Eles põem muito fiscal na roça. Para cada pessoa, tem dez olhando. Se você pegasse todo mundo, dava uma turma para cortar cana [...]. (Jair). 
Além do fiscal tem o monitor, o medidor, o gerente.

Primeiro, tem o monitor... É só para ajudar quem não sabe cortar, explicar como faz como amola o facão... Ele corta um pouquinho no eito de um, no eito de outro. (Antônio).

O monitor em geral já foi cortador, um bom cortador. O próximo é o medidor:

O medidor tem que medir a cana que o pessoal corta e olhar os eitos também, olhar o serviço, se o toco está baixo, se não tem gomo de cana nas pontas. (Antônio).

O fiscal geral, o trabalho dele além de fiscalizar, é quem fala: "olha a turma de fulano de tal vai pegar tal talhão". É ele quem solta o trabalho para as turmas, ele é o encarregado por parte da usina em distribuir o serviço para as turmas... Como diz o ditado, é o manda-chuva. (Jair).

Em uma de nossas observações no talhão, viemos, a saber, os eitos eram irregulares em suas formações, apresentando maiores dificuldades para o corte nos locais onde se encontram os declives com curvas de nível, quando a cana se encontra caída ou então entrelaçada, mas a recusa ao trabalho era considerada como algo inadmissível. Por esse motivo, para os eitos de maiores obstáculos, havia a necessidade de organizar o trabalho através de uma escala com nomes dos componentes da turma, um instrumento de imposição e controle do trabalho, a fim de garantir a maximização da produção no corte da cana. Para isso, os fiscais são pagos para exercerem o "olhar" constante sobre os trabalhadores.

O talhão é o espaço da redução do trabalhador a tempo de trabalho, a trabalho abstrato. Para isso, os mediadores da dominação, como se viu, exercem o "olhar" constante sobre eles. Os próprios fiscais não possuem parentes na turma para poderem "olhá-la" melhor. Esse "olhar" não pode ser generalizado, a ponto de se perder no horizonte do canavial ou se confundir no meio das ruas de cafeeiros e laranjeiras. É necessário um "olhar" minucioso, controlando cada gesto, cada ritmo, cada conduta. (SILVA, 1999, p. 151).

Os estudos de Foucault descrevem a sociedade disciplinar: "A disciplina procede em primeiro lugar à distribuição dos indivíduos no espaço" (Foucault, 2008, p.121). A organização espacial, horários, escala hierárquica, tudo leva a essas instituições a prescrição de comportamentos humanos estabelecidos e homogêneos, assim como descreve Foucault (2008):

A minúcia dos regulamentos, o olhar esmiuçante das inspeções, o controle das mínimas parcelas da vida e do corpo darão, em breve, no quadro da escola, do 
quartel, do hospital ou da oficina, um conteúdo laicizado, uma racionalidade econômica ou técnica a esse cálculo místico do ínfimo e do infinito. (FOUCAULT, 2008, p. 121).

É importante destacar para Foucault, o efeito do poder disciplinar é a fabricação de corpos dóceis, ou seja, corpos maleáveis e moldáveis conforme as exigências dos mecanismos disciplinares, isso significa que, por um lado, o corpo se submete a disciplina com o intuito de produzir um ganho de força pelo incremento de sua utilidade e, por outro lado, perde força pela sua sujeição à obediência política. Como explicita o autor "[...] se a exploração econômica separa a força e o produto do trabalho, digamos a coerção disciplinar estabelece no corpo o elo coercitivo entre uma aptidão aumentada e uma dominação acentuada" (Foucault, 2008, p.119).

Todo esse controle e poder são alimentados por uma série de punições aos trabalhadores, desde reprimendas e ameaças verbais até a demissão. A carga laboral diante do desgaste na realização das tarefas e a necessidade de maior dispêndio físico, ao se manifestar enquanto recusa ao corte da cana, apresentar-se-ia - ao cortador individualmente diferenciado no microcosmo do eito - como uma relação conflitiva com o poder de mando e a insegurança de não poder ser contratado para a próxima safra. Por isso, a necessidade de ser o "número um", não se abstendo do trabalho e não criando confusões e atritos.

Em nossa investigação, um dos fiscais de área, contratado pela usina, ao observar o corte da cana, contou-nos sua tarefa no talhão era medir a quantidade de cana a ser cortada e garantir a execução do serviço. De acordo com Silva (1999), os físcais são como um instrumento de dominação no canavial: "Para isso os mediadores da dominação, exercem o olhar constante sobre eles. É necessário um olhar minucioso controlador de cada gesto, cada ritmo, cada conduta" (SILVA, 1999, p.152).

Eu acho mais cansativo é você estar cortando cana e o fiscal do seu lado (...) Não pode trabalhar direito (....) Você não trabalha sossegado. Fica meio inibido. Os fiscais, eles têm aquele poder de falar e tem horas que eles não tratam a gente nem como gente: é como cachorro. É [dá um assobio]... assobiando! A maior humilhação do mundo é o corte de cana. (João).

Foi possível observar, o eito destinado a cada cortador era formado por cinco ruas de cana, e estes trabalhadores chegavam a cortar em média de dois a três eitos em um dia de trabalho. Na usina, os trabalhadores recebem por produção, isto é, depois da cana ser 
medida em metro pelo fiscal de campo, essa medida é convertida em tonelada. Quer dizer, teoricamente, como admitiu o trabalhador Paulo, quanto mais peso tiver a produção, maior seria o ganho dos cortadores de cana. Conforme se verifica em seu relato

\footnotetext{
"Eu acho melhor por produção. A produção torna mais fácil, melhor. Dá para tirar mais. Depende também do cara, entendeu? [...] Assim, quando o cara produz bastante, quando o cara é bom de cana, o salário é justo para ele, mas quando cara é ruim". (Paulo).
}

O processo de informatização das planilhas de execução das tarefas e o controle sobre o volume da produção dos cortadores de cana a cada dia de trabalho e em cada eito, bem como a probabilidade e a meta a ser alcançada no final de cada mês permitiram ao usineiro maior controle da produção em relação à quantidade e a qualidade da cana, e, consequentemente, maior volume de produção. Foi relatada a necessidade de subordinar aos "superiores" sob pena de ser demitido ou não mais ser contratado, conforme se verifica no relato:

O medidor falou que quem não respeitasse ele, na hora que ele fosse medir a cana, ele roubava de qualquer um e ninguém ficava sabendo [...]. (Everaldo)

Tinha um eito de 335 metros... o medidor mediu 258 metros, eu desconfiei... Aí, eu falei para o fiscal. O fiscal falou: "se der menos, vou descontar de você e te dar uma advertência; se der mais, é seu". Eu fui medir, deu 350 metros. Eu não levei advertência, porque estava certo... se tivesse faltando eu ia levar advertência [...]. (Adair)

$\mathrm{Na}$ terça-feira, os tocos ficaram altos... tinha muita pedra e fazia muito dente no facão... O fiscal geral chegou e falou: "não vou medir cana de ninguém enquanto não repassar os tocos". A turma até falou que concordava mas se ele medisse a cana [...]. João

Porque se a gente quer passar fixo a gente não pode reclamar de nada. Porque se reclamar ele [fiscais] ficam em cima da gente: 'Não é desse jeito não. É desse. Se vocês reclamarem alguma coisa de valentia vocês saem da usina sem direito, sem nada'. E a gente não diz nada. (Igor)

Na usina, tem a média de cortar cana; se cortar menos de 8 toneladas, inclusive no domingo, eles mandam embora. (João)

Os trabalhadores parecem estar mais presos à mercê dos interesses dos donos dos guinchos mecanizados da tecnologia de produção e, principalmente, dos maquinários no corte de cana, nesta nova e última fase do seu processo de adaptação aos declives dos talhões. Podemos observar na foto (2), a cana sendo levada pelo maquinário após ser cortada e medida pelos fiscais. 
O trabalho no corte da cana envolve aprendizado e uma classificação daquele que o realiza. Está habilitado a fazê-lo corresponde especificamente, no trabalho por produção, e um treinamento do corpo perante as condições adversas desta tarefa.

A habilidade com o facão e a resistência frente às posições assumidas pelo corpo, dada às situações dos eitos, permitem não só aos trabalhadores, mas também e principalmente aos fiscais e outros mediadores no processo de produção, classificar a qualidade do trabalho em relação à quantidade e ao tempo despendido na colheita da cana, estabelecendo-se, inclusive, disputa pelos melhores cortadores. Quando questionado sobre os quesitos necessários para ser contratado, o trabalhador responde: "Precisa cortar não sei quantas toneladas de cana aí, o cara tem que ser bom. Bom cortador, né?”. Na análise de Silva:

Isto é conseguido por intermédio da forma de pagamento (por tonelada) e também pela concorrência velada que se estabelece entre os trabalhadores, diferenciando-os, hierarquizando-os. Produz-se, assim, a figura do "bom cortador de cana", aquele que corta em torno de dez toneladas diárias. Aqueles que estão muito abaixo desta média sentem-se incapazes, envergonhados, inferiorizados. Pelo jogo desta quantificação, os aparelhos disciplinares hierarquizam, mediante a emulação, os "bons" e os "maus" indivíduos. (SILVA 1999, p.202).

Foto 2: Usina Laginha Agroindustrial S/A- Unidade Trialcool

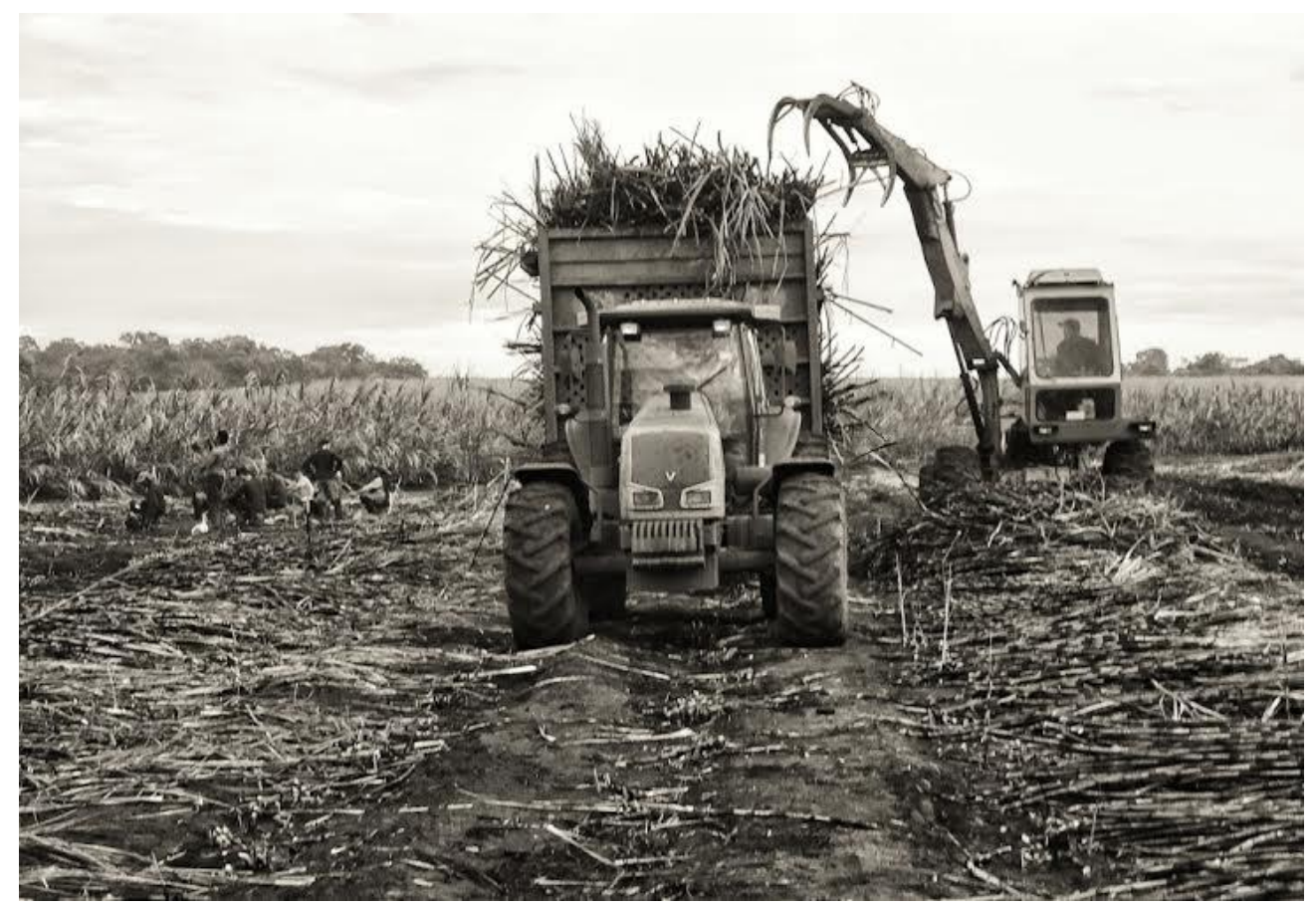

Autor: ARAÚJO, D. F. C. (2012). 
Traçando um paralelo entre o pensamento de Foucault sobre as prisões e outras tecnologias disciplinares, é perceptível no ambiente de trabalho, mas, particularmente, no trabalho do corte da cana, parâmetros e tecnologias percebidos por Foucault para moldar o "espírito" dos prisioneiros a se fazerem presentes.

Para Foucault (2010) o indivíduo sob vigilância produz mais, melhor e quase não cometem erros, também não tem distrações, nem espaço para o ócio. O simples fato de crer que está sendo vigiado é suficiente para seguir as regras e se manterem produtivos. "O poder disciplinar é, com efeito, um poder, em vez de se apropriar e de retirar, tem como função maior "adestrar"; ou sem dúvida adestrar para retirar e se apropriar ainda mais e melhor. Ele não amarra as forças para reduzi-las; procura ligá-las para multiplicálas e utilizá-las num todo" (FOUCAULT, 2008, p. 190). Assim, foi possível evidenciar essa disputa entre os trabalhadores no final do dia de trabalho. Quando estávamos retornando para o alojamento, os trabalhadores conversavam entre si sobre a produção do dia de trabalho e alguns exaltavam seu desempenho no tempo gastado na colheita da cana.

\footnotetext{
Minha média é na base de 11, 12 toneladas, por aí, 13 [...] Dependendo da cana[...]. (Igor).
}

Minha tonelagem é de nove pra frente [...]. (Antônio).

Minha tonelagem eu não sei. Sei mais por metragem que é o primeiro ano que corto cana. Eu comecei com 50, 60, 70... Eu sei que já estava cortando quase 300 metros de cana, que são 1.500 metrinhos, no eito de 5 ruas". (Adair).

Para esses trabalhadores desempenhar as atividades de cortadores de cana, é necessário se paramentar com EPI's (Equipamentos de Proteção Individual), como camisetas de manga longa, chapéus, botas com caneleiras, óculos e luvas. Além disso, são obrigados a conviver com o perigo de incêndio.

Os equipamentos são entregues no início da safra aos trabalhadores e caso seja necessário à troca, os mesmos arcam com o custo dos EPI's. Eles são de extrema importância para a segurança do trabalhador, e evitam acidentes no local de trabalho. Relatos realizados pelos trabalhadores migrantes demonstram um baixo índice de 
acidentes no campo, fruto principalmente da normativa NR312 ${ }^{13}$ que estabelece o cumprimento das obrigações das agroindústrias canavieiras, no sentido de implantar medidas de modo a garantir a segurança e a saúde dos trabalhadores nos canaviais.

Alguns relacionam também dores com o uso de luva de proteção, principalmente, quando começam a cortar cana:

Na primeira semana que o cara usa luva dói a mão mesmo, o cara quase não pode fechar, a luva atrapalha mesmo. (Antônio).

Têm muita gente que não acostuma com a luva, porque com a luva a gente tem que dar um golpe mais duro. Eu mesmo só uso luva na mão que pego a cana. Porque na outra mão não consigo pegar o podão com a luva, parece que meu pulso não segura, o podão escapa. (Francisco).

Entretanto, a falta de luva cria uma série de problemas nas mãos: calos, bolhas, rachaduras. No trabalho de campo, podemos observar muitos indivíduos trabalharem com a mão com muitas feridas na base do indicador.

Foi até que enfim, emborrachei o cabo do facão e amenizou um pouco a coisa. Cortei uma faixa de pneu de bicicleta e enrolei no cabo. Foi quando pareceu que segurou mais, aí (minha mão) parou de rachar e eu passando um creme (remédio) direto. (Adair).

Contudo, a posição para a realização desta tarefa exige do trabalhador um adestramento do corpo, um aprendizado ao lidar com o facão, bem como o estilo adotado frente às exigências dos mediadores da produção, pois o corte da cana deve ser executado em ambas as extremidades da planta, ou seja, rente ao solo e depois em sua parte superior. E, dependendo da época, da empresa, apanha-se determinada quantidade de cana na touceira aplicando um número de golpes, depois cortar o ponteiro de cada peça para eliminar a ponta da cana e manter garantida a concentração de sacarose a fim de facilitar o transporte.

Laat (2010) concluiu em média, os cortadores de cana desferem 3.498 golpes de facão, realizando 3.080 flexões de coluna, cortando em média 12,9 toneladas por dia. Os batimentos cardíacos chegam a duzentos por minuto. A maior parte dos trabalhadores nessa atividade extrapola a carga cardiovascular limite, ou seja, tem uma grande

${ }^{13}$ Normas que visam regulamentar medidas de segurança e saúde no trabalho na agricultura, pecuária, silvicultura, exploração florestal e aquicultura do trabalhador. https://enit.trabalho.gov.br/portal/images/Arquivos_SST/SST_NR/NR-31.pdf. 
sobrecarga na frequência cardíaca. Conforme se pode depreender do relato de um dos entrevistados: "Aí passa do limite da gente, não pode, já fica ruim já. Ai não come nada, vomita, dá câimbra. Mas é normal de se ver" (Paulo).

É quando dá essas cãibras. Coisa ruim moço! Coisa ruim demais [...]. $\mathrm{O}$ coração da gente fica voc, voc, voc. O ouvido da gente parece que vai estourar. Ai a gente tem que parar [...]. O coração da gente fica batendo ligeiro: tan, tan, tan. A gente passa a mão aqui na gente pra vê se melhora. Ai tem que sentar. (Francisco).

Os cortadores de cana também ingerem grande quantidade de água, em média, oito litros em um dia de trabalho ao cortar sete toneladas de cana, com um gasto médio de 3.518 calorias, caminhando até dez quilômetros (VERÇOZA, SILVA 2012). Desse modo, convivem com dores cotidianas, como câimbras, vômitos, tonturas e machucados - cortes nas mãos e pés pelo manuseio do facão. As dores nos braços, decorrentes do esforço contínuo feito para cortar cana, são comuns entre os cortadores:

\footnotetext{
Eu sinto dor neste braço (direito) que vai das pontas dos dedos até aqui (ombro)... Fica dormente, dói que não tem onde por o braço, tem que levantar da cama e por o braço pra cima. Se a dor começar a meia noite não durmo mais... Isto começou quando eu comecei a cortar cana. Foi um presente que ganhei e acho que vou morrer com ela. (Everaldo).
}

A sobrecarga térmica também age contra a saúde do cortador de cana, podendo levar as chamadas doenças de calor, como irritabilidade, confusão mental, câimbras, fadiga e até mesmo morte (Bittencourt et al., 2012). Além disso, a queima da cana, a fuligem e fumaça, que provocam problemas respiratórios, também representam um aquecimento da terra, e contribui para a sobrecarga térmica. As vestimentas pesadas impedem o corpo de fazer a troca de calor para a manutenção do equilíbrio térmico do corpo.

\footnotetext{
Agora, dor no meu corpo eu tenho demais. Se fosse outra pessoa [...] passando mal pra caramba ficaria aqui. [...] Rapaz, é pior ficar no alojamento. Porque se você não tiver um atestado médico, vão pôr falta pra você. E o que você vai ganhar? Não vai ganhar nada! Ai tua quinzena vem magra. Tem que ir. Tem que ir de qualquer jeito. Ou bom ou ruim tem que ir. Se o cara tiver passando muito mal aí o cara vai assinar lá o papel e fica no busio [ônibus] até a hora de ir embora. (Paulo).
} 
Os trabalhadores migrantes sazonais trabalhavam quarenta horas semanais, geralmente de segunda a sábado e ocasionalmente também aos domingos, por volta de 8 horas diárias com grande esforço físico, em longo prazo, esse trabalho desenvolvido nessa frequência acarretou grandes prejuízos à saúde desses trabalhadores do corte da cana-deaçúcar.

Dá assim em mim um problema que quando eu deito na cama dói demais... Aí eu peço a Deus para o dia amanhecer pra eu fica caminhando pra cima e pra baixo. Mas a gente tem que aguentar pra consegui uma condição melhor [...]. Não dói as costas todo dia não, porque eu tomo uns comprimidos. Aí alivia, né? Mas quando passa três dias sem tomar, torna a doer [...]. (Everaldo).

Os cortadores de cana são unânimes em considerar as radiações solares e as chuvas como principais agentes de desgastes e fadiga no trabalho.

Eu já me cortei no caso de chover e eu continuar cortando cana. Então, o cabo do facão fica muito liso... A gente está querendo trabalhar para não perder o dia, escorrega, $[\ldots]$ porque tem aquelas valetas, que eles plantam cana do primeiro corte, o sulco, o barro, a gente escorrega [...]. (João).

O calor escaldante era amenizado apenas quando ocorriam as rajadas de vento. Entretanto, desconfiamos, pois, este fato não trazia maior conforto aos cortadores, por seus corpos se encontrarem totalmente cobertos. Na foto (3), podemos observar um trabalhador no final da sua jornada de trabalho.

Olha, quando o cara corta demais, passa dos limites. Ai começa dar cãibra, aqueles enjoos pra vomitar. $\mathrm{O}$ sol muito quente, começa dar cãibra em toda parte do corpo, nossa! Forcei muito. [Deu cãibra] aqui (mostra a perna). E enjoou também. (Adair). 
Foto 3: Trabalhador cortando cana na Usina Laginha Agroindustrial S/A- Unidade Trialcool

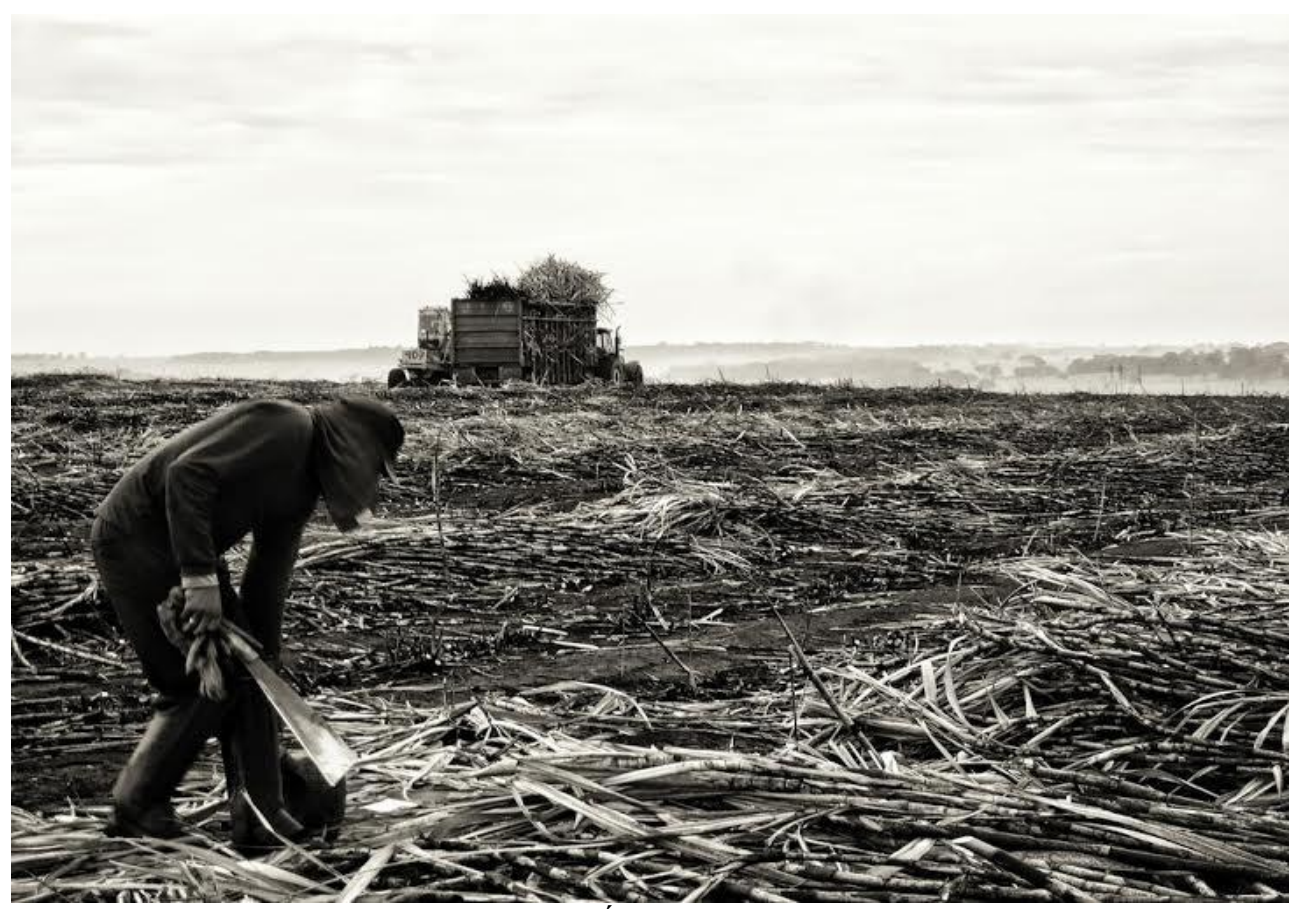

Autor: ARAÚJO, D. F. C. (2012)

Assim, estes cortadores de cana migrantes trabalham de forma intensa, e apesar de não haver uma cobrança direta por produção, procuram aumentar sua produção diária, pois assim seus rendimentos serão maiores ao final da safra. O salário é pago mediante a produção, ou seja, as toneladas cortadas, incentivando a trabalharem "como máquinas", devido ao irrisório preço pago pela tonelada de cana cortada. Conforme informações disponibilizadas pelos trabalhadores, as agroindústrias canavieiras pagam em torno de $\mathrm{R} \$$ 4,30 por cada tonelada de cana queimada e $\mathrm{R} \$ 6,30$ pela cana crua. Essas empresas muitas vezes usam de má fé para explorar esses trabalhadores, muito deles não sabem calcular o valor produzido.

Entretanto a despeito de todas as implicações negativas para os cortadores de cana, a maioria deles é favorável à continuidade desta forma de remuneração. Muitos estudiosos têm se debruçado há décadas sobre o estudo da agroindústria canavieira viram-se diante deste dilema. Silva (1999) e Novaes (2009) são alguns dos exemplos de pesquisadores ao apontarem essa preferência por parte dos trabalhadores rurais. Nas palavras de Novaes:

No local de origem, são diversas as situações vivenciadas pelos trabalhadores migrantes que se dispõem a viajar para o trabalho nos canaviais paulistas. Mas há um denominador comum entre eles: todos valorizam o trabalho no corte da 
cana, onde o ganho é pela produção. Quanto mais se corta, mais se ganha. Assim, os trabalhadores nordestinos chegam à região com a disposição de acionar toda sua força física, toda habilidade e resistência para alcançar boa produtividade. (NOVAES, 2009, p. 64-65)

O salário pago aos cortadores de cana é calculado a partir de sua produtividade, pode-se dizer seu ganho, ou seja, o aumento da produção, e a consequente "melhoria", na sua condição de vida, vão depender justamente de sua capacidade física (ELIAS, NAVARRO, 2006). No caso dos cortadores de cana, pode-se afirmar o "esforço realizado pelos trabalhadores é decorrente do processo de trabalho combinado com a forma de pagamento" (ALVES, 2008, p. 2).

O pagamento por produção garante à empresa a intensificação e aumento das jornadas de trabalho, e para garantir maiores ganhos os trabalhadores se submetem há altos níveis de esforço laboral físico. Na usina, o horário de almoço é fixo. Porém, os cortadores são unânimes em afirmar, uma vez iniciado o trabalho não é bom parar.

\footnotetext{
O ideal é não perder tempo mesmo, tem que ser ligeiro mesmo pra cortar, tem que ser bom... O normal de um cortador é descontar 20 minutos no almoço e mais 10 minutos no café... É, come rapidinho e já pega de novo. E aí vai até uma certa hora da tarde e aí para, e já pega outra vez em seguida. Praticamente não descansa nada (Antônio).

Na usina, eles dão soro que fica na mochila, a hora que via dar câimbra, ia lá e tomava, esperava um pouco, depois continua (no trabalho). Agora, eles não dão mais soro. Se a gente quiser sarar, a gente tem que fazer soro caseiro: mistura lá, põe um pouco de água e açúcar e bebe[...]. (Francisco).
}

Além desse primeiro aspecto, não se pode deixar de ressaltar, com o passar do tempo, a média diária a ser atingida pelos cortadores de cana aumentou significativamente.

Com isso, é possível perceber a imposição de uma média diária cada vez maior para funcionar como o definidor do aumento da produtividade do trabalho dos cortadores de cana, como já mencionado, é obrigado a atingir a meta estipulada para conseguir assegurar seus postos de trabalho. Nesse contexto, caracterizado por pressões e cobranças por parte das usinas e por demissões daqueles que não conseguem atingir a média, a rotatividade dos cortadores torna-se muito alta.

Segundo os entrevistados, é diretamente relacionada com a produtividade de "sua turma", composta pelos trabalhadores que fiscaliza. E por conta desse fato os trabalhadores afirmam: os fiscais acabam por exigir mais empenho dos trabalhadores, 
mesmo diante de situações nas quais os trabalhadores demonstram cansaço ou se queixam de dores, como demonstra o relato:

Ele [fiscal] diz: 'rapaz, você tá doente? Rapaz, vamo embora trabalhar! Levanta, trabalha.' (...) E a gente morto fala: 'não posso, não posso'. E ele: 'vai trabalhar, vai trabalhar'. Quando a gente está com esses problemas [de muito cansaço] a gente vai para o busio [ônibus] por conta da gente. (Igor).

Conforme Lourenço \& Bertani (2010), a escolha pela força de trabalho migrante representa vantagens para o capital, já os encargos trabalhistas e sociais se restringem apenas ao período da safra; trata-se de uma mão de obra mais barata e mais resignada. A distância da família e as adversidades da viagem resultam numa maior subordinação às imposições do trabalho, a possibilidade de retorno a sua região de origem é remota, principalmente pela questão financeira. Alguns são selecionados no local de origem, e com o fim da safra devem voltar a esses locais, a fim de serem recontratados nas safras seguintes.

Os trabalhadores comprometem sua saúde, por se posicionar de forma curvada, ação necessária para o corte da cana e uma das principais causas de doenças ocupacionais. Além disso, a queima da cana causa problemas respiratórios, como destaca o professor José Josberto Montenegro Sousa em entrevista concedida no documentário "Nas trilhas da cana" vinculado ao Laboratório de Geografia Humana e Ensino (LAGHEN), da Universidade Federal de Uberlândia, Campus Pontal, em março de 2013: "os trabalhadores do corte da cana sofrem com dores sentidas após um mês de trabalho, é coluna, são essas articulações do braço, do antebraço, todos eles começam a ter inflamações, além da questão respiratória”. Esses trabalhadores passam o dia em uma determinada posição realizando movimentos repetitivos com "fiscais em seus calcanhares" estando sob rígido controle das agroindústrias. Quando voltam para casa os cortadores estão extenuados:

Tem dia da gente chegar no alojamento, não vai nem tomar banho, e nem quer jantar, já vai dormir. E no outro dia é que levanta mais cansado de manhã cedo [...] porque tem hora que a gente está trabalhando, nem sente a canseira. Depois de manhã cedo, a gente vai ver, quando o corpo esfria, como é que a gente está [...] está tudo doendo [...] A gente tem que chegar na roça e fazer o corpo acostumar de novo [...]. (João). 
Ao final do dia, estavam todos em torno do ônibus esperando para ir para o alojamento organizando o material para o dia seguinte e preparando o jantar. $\mathrm{Na}$ foto (4) a seguir, podemos ver os trabalhadores à espera do chamado dos fiscais.

Foto 4: Trabalhador no final da jornada de trabalho na Usina Laginha Agroindustrial S/A- Unidade. Trialcool.

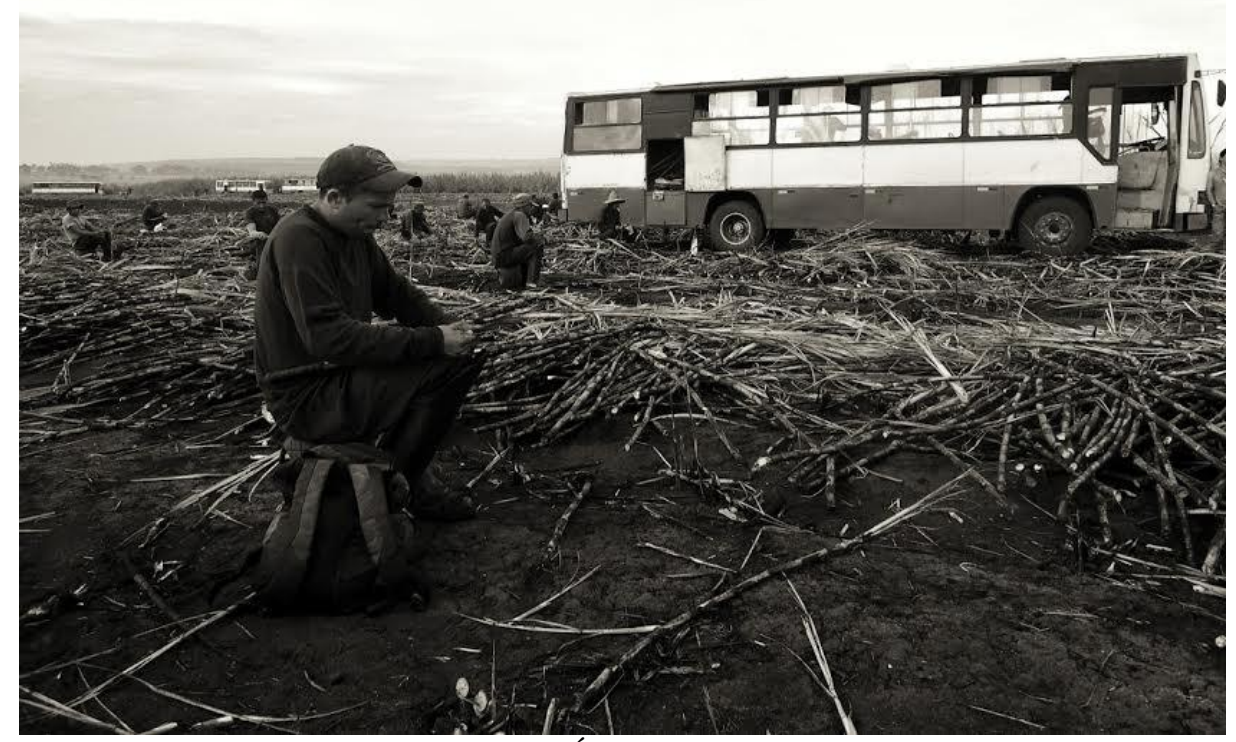

Autor: ARAÚJO, D. F. C. (2012).

Ao chegarem a seus alojamentos após um extenuante dia de trabalho, cerca de 15 horas e 30 minutos, ainda precisam se dedicar aos afazeres domésticos, como lavar a roupa, limpar o quarto, ao configurar uma jornada exaustiva, chegando exauridos ao final do dia.

A alimentação constituída por arroz, feijão, mandioca e pequenos pedaços de carne fornecida pela agroindústria canavieira, paga pelos próprios trabalhadores é pobre em nutrientes necessários à sustentação de seu corpo físico, é alvo de críticas por parte dos trabalhadores, visto além de não possuir uma variedade em seu cardápio, é servida fria.

Devido à insuficiente alimentação fornecida pelas agroindústrias instaladas na Microrregião de Ituiutaba, esses trabalhadores complementam sua alimentação comprando em supermercados locais: ovos, verduras, alimentos em conserva, dentre outros, e preparam um reforço alimentar. 
Além da preocupante condição de trabalho, vivem alojados em albergues espalhados por vários locais da cidade, sendo descontado mensalmente o valor do alojamento, onde nota-se até mesmo a inexistência de higiene. Os trabalhadores são colocados em quartos de tamanho reduzido com pouca ou nenhuma ventilação, com beliches onde ficam quatro homens, o que leva muitos deles a espalharem colchões em outras áreas mais arejadas do alojamento.

Algumas proibições expressas pela usina demonstram uma tentativa de controlar o tempo livre dos trabalhadores. É proibido o pernoite de esposas, namoradas ou prostitutas, e até mesmo parentes como visitas. A justificativa das respostas dos encarregados da usina para fundamentar essa regra circula em torno da ideia de que o alojamento é um espaço de descanso. Faz-se o máximo para evitar eventos, pois pode atrapalhar o descanso dos trabalhadores. Isso revela uma intenção da usina de controlar o tempo livre, o trabalhador mais descansado terá melhor produtividade no trabalho. A mesma argumentação serve para a proibição da utilização de televisores nos quartos. No alojamento, existe uma sala com uma televisão, ligada cotidianamente até às 21 horas, com exceção das quartas-feiras, noite de jogos de futebol, a TV fica ligada até às 23 horas, se algum trabalhador desejar assistir. Após esse horário, o físcal desliga e todos são convidados a dormir.

Estas duas regras buscam regulamentar o tempo livre dos trabalhadores com a finalidade de zelar pelo seu descanso e aumentar consequentemente a produtividade, só é possível se os trabalhadores morarem na propriedade da usina. O segundo elemento leva a crer que a usina busca controlar o tempo livre dos trabalhadores, é o fato do fiscal morar no alojamento e executar as regras prescritas pelo corpo diretor da usina. O fiscal é responsável pela vigilância do alojamento, encarregado de proibir a hospedagem de mulheres ou parentes; e garantidor do silêncio durante o período de descanso. O terceiro elemento evidente de tal iniciativa é o fato de, ao lado de cada alojamento de trabalhadores desta usina, se encontram as casas dos encarregados.

Levando em considerações estas condições vivenciadas pelo migrante, Mendonça contextualiza:

Há um conjunto de situações que denotam formas degradantes de trabalho (alojamentos precários, falta de equipamentos de segurança, condições de trabalho insalubres e alimentação inadequada, entre outras) para os trabalhadores safristas e de forma piorada para os trabalhadores temporários. (MENDONÇA, 2004, p.266). 
É de extrema relevância desmitificar a ideia do trabalhador utilizado como mão de obra nos canaviais ser bem remunerado. A esse respeito, o professor Marcelo Mendonça (2013), destaca em entrevista ao documentário "Nas trilhas da cana": "de fato existem cortadores de cana com ganhos mensais em torno aí de dois mil reais, o que a mídia retrata como algo estrondoso, como se alguém que ganhe três salários mínimos pudesse viver bem com sua família nesse país".

\section{Considerações Finais}

Neste contexto, é reforçada a tese do processo de intensificação da superexploração e força de trabalho utilizada pelo capital para obter a mais-valia e lucro, pois coloca o trabalhador sob uma condição precária de trabalho. Levando-o ao esgotamento prematuro das suas forças físicas, e não lhes garante um salário digno necessário à sua sobrevivência e de seus familiares.

Diante dos desafios próprios do deslocamento para o trabalho, a baixa remuneração do setor para o trabalho agrícola e a inserção em uma região com traços culturais diferentes; a presença destes migrantes revela o poder que o setor possui em redefinir as condições de trabalho na produção do setor sucroenergético.

O status do cortador de cana, seja no local de trabalho, seja com a família e amigos, vai depender de seu desempenho ao fim da safra. Cortou-se muito, ganhou dinheiro suficiente, ganhará respeito, reconhecimento; senão, fica conhecido como "podão de borracha", um fraco. Há um peso simbólico da associação entre desempenho no trabalho e a identidade.

O pensamento patriarcal mantém sobre o homem a responsabilidade de manutenção da família. Entretanto, o patriarcado não está restrito ao campo do trabalho, está em todas as esferas das relações sociais. Voltar para o local de origem, voltar com uma quantia de dinheiro e garantir o conforto da família, significa reafirmar esse papel. É também essa cobrança motivadora faz os cortadores se dedicarem até o limite do seu corpo, mesmo que resulte em adoecimento físico ou psíquico. Esse adoecimento repercute sobre as famílias, pois as mulheres passam a desempenhar outros papéis quando ao retorno de seus esposos sem capacidade laboral para retomar seu papel na agricultura familiar. 


\section{REFERÊNCIAS}

ALMEIDA, P.; MORAES, S. P. Em movimento: trabalho em canaviais e trajetórias de trabalhadores no Triângulo Mineiro nas últimas décadas. Revista Mundos do Trabalho. Florianópolis, vol. 4, n. 7, 2012, p. 146-162. Disponível em: <http://dx.doi.org/10.5007/1984-9222.2012v4n7p146> acesso maio 21 de 2020.

ALVES, F. Por que morrem os cortadores de cana?2018-Saúde e Sociedade. v.15, n 3, p. 90-98, set-dez 2006. DOI https://doi.org/10.1590/S0104-12902006000300008. Acesso em: 21 maio de 2020.

ALVES, G. O novo (e precário) mundo do trabalho: reestruturação produtiva e crise do sindicalismo. São Paulo, BOITEMPO, 1991.

ARAÚJO, D.F.C. O lado amargo da cana: estudos sobre trabalhadores migrantes no setor sucroenergético no pontal do triângulo mineiro. 2018. 179 f. Dissertação (Mestrado) - Curso de Programa de Pós Graduação em Ciências Sociais, Instituto de Ciências Humanas, Universidade Federal de Uberlândia, Uberlândia, 2018. Cap. 4.

ARAÚJO, N. S. de. A precarização das relações de trabalho no setor sucroenergético no município de Ituiutaba (MG). 2019. 173 f. Dissertação (Mestrado em Geografia) - Universidade Federal de Uberlândia, Ituiutaba. 2020. Disponível em: http://dx.doi.org/10.14393/ufu.di.2019.2281.

BERNARDES, J. A. Novas fronteiras do capital no Cerrado: dinâmica e contradições da expansão do agronegócio na região Centro-Oeste, Brasil. Scripta Nova (Barcelona), v. XIX, p. 1-28, 2015.

BITENCOURT, Daniel Pires; RUAS, Álvaro César; MAIA, Paulo Alves. 2012 Análise da contribuição das variáveis meteorológicas no estresse térmico associada à morte de cortadores de cana. Caderno Saúde Pública, Rio de Janeiro, v. 28, n.1, jan. 2012.

BRAY, S. C. As Políticas do Instituto do Açúcar e do Álcool e do Programa Nacional Álcool e Suas Influências na Área Açucareira - Alcooleira de Catanduva. In: RUAS, Davi Guilherme Gaspar; FERREIRA, Enéas Rente; BRAY, Sílvio Carlos (Orgs.). A agroindústria sucroalcooleira nas áreas canavieiras de São Paulo e Paraná. 1. ed. Rio Claro: IGCE/UNESP - Pós-Graduação em Geografia, 2014. v. 1. 213p.

BRAY, S. C. O Proálcool e as transformações nas áreas canavieiras do estado de São Paulo.

CARVALHO, R. G.; SANTOS, J.C.; SILVA, L. C. S. A expansão do setor sucroenergético na microrregião geográfica de Ituiutaba $(\mathrm{mg})$ e a degradação do trabalhador canavieiro. Revista Pegada Eletrônica (Online), v. 14, p. 189-208, 2013. DOI: https://doi.org/10.33026/peg.v14i1.2096

CAMELINI, J. H. Regiões Competitivas do Etanol e Vulnerabilidade Territorial no Brasil: O Caso de Quirinopolis, GO. 2011. Dissertação (Geografia), UNICAMP.2011. 
CARVALHO, Josiane Fernandes de. Precarização e trabalho Precarização e trabalho no corte de cana no noroeste paranaense. In: IV SIMPÓSIO LUTAS SOCIAIS NA AMÉRICA LATINA, 4., 2010, Londrina. Anais do IV Simpósio Lutas Sociais na América Latina. Londrina: Londrina, UEL, 2010. v. 4, p. 133 - 143.

CASTILlo, R. A. Exportar Alimentos é a Saída para o Brasil? O caso do complexo da soja. In: ALBUQUERQUE, Edu Silvestre (org.). Que país é esse? Pensando o Brasil contemporâneo. São Paulo: Globo. 2005.

CLEPS JR., J. Concentração de poder no agronegócio e (des) territorialização: os impactos da expansão recente do capital sucroalcooleiro no Triângulo Mineiro.

Caminhos de Geografia. Uberlândia, v. 10, n. 31, p. 249-264, 2009.

DELGADO, G. C. Do Capital Financeiro na Agricultura à Economia do Agronegócio: Mudanças Cíclicas em Meio Século: (1965-2012). 1a. ed. Porto Alegre- RS: Editora da UFRGS, 2012. v. 01. 142p.

ELIAS M.A., Navarro V.L. A relação entre o trabalho, a saúde e as condições de vida: negatividade e positividade no trabalho das profissionais de enfermagem de um hospital escola. Rev. Latino-am Enfermagem 2006 julho agosto; 14(4):517-25.

ELIAS, D. Agronegócio e novas regionalizações no Brasil. R. B. Estudos Urbanos e Regionais. V. 13, N. 2, 2011. https://doi.org/10.22296/2317-1529.2011v13n2p153

ELIAS, D. Globalização e Agricultura. São Paulo: EDUSP, 2003.

ELIAS, D. Globalização e fragmentação do espaço agrícola do Brasil. Scripta Nova. Barcelona / Espanha, v. 1, p.59-81, 2006.

FOUCAULT, Michel. Vigiar e punir: nascimento da prisão. Tradução de Raquel Ramalhete. Petrópolis: Vozes, 2008.

FREDERICO, S. "Modernização da agricultura e uso do território: a dialética entre o novo e o velho, o interno e o externo, o mercado e o Estado em áreas de Cerrado". GEOUSP: espaço e tempo, São Paulo, v. 33, p. 46-61, 2013.

FREDERICO, S. Região e Modernização Agrícola. In: BERNARDES, J. A.; SILVA, C. A. da; ARRUZZO, R. C. (Org.). Espaço e energia: mudanças no setor sucroenergético. Rio de Janeiro: Lamparina, 2013. p.99-111.

IBGE- Instituto Brasileiro de Geografia e Estatística. SIDRA. Banco de Dados Agregados. Disponível em: Acesso em: 10. dez, 2019.

LAAT, E. F. Trabalho e risco no corte manual de cana-de-açúcar: A maratona perigosa nos canaviais. 2010. Tese (Doutorado em engenharia de Produção) - Faculdade de Engenharia,Arquitetura e Urbanismo, Universidade Metodista de Piracicaba, Santa Bárbara D'oeste,2010. 
LOURENÇO, E. Â. S.; BERTANI, I. F. The work and health process in the sugar cane industry in Franca, Brazil. 2010.International Social Work, [s.n.], set.10, p. 1-13, 2010.

MATOS, Patrícia Francisca de. As tramas do agronegócio nas terras do Sudeste Goiano. 2011. 357 f. Tese (Doutorado em Ciências Humanas) - Universidade Federal de Uberlândia, Uberlândia, 2011.

MATOS, P. F.; FRATARI, M. F.; CARVALHO, R. G. Fim do corte manual da canade-açúcar na microrregião de Ituiutaba (MG) e os impactos para os trabalhadores.

Caminhos da Geografia (UFU. Online), v. 19, p. 194-203-203, 2018. DOI:

https://doi.org/10.12957/geouerj.2018.29749

MENDONÇA, M. R. A urdidura espacial do capital e do trabalho no cerrado do

Sudeste goiano. 2004. 448 f. Tese (Doutorado em Geografia) - Faculdade de Ciências e Tecnologia, UNESP, Presidente Prudente, 2004.

NERY, N. C. S.; SANTOS, J. C. O fim do corte manual da cana-de-açúcar e o 'fim' do cortador de cana: a conjuntura dos trabalhadores migrantes na microrregião de Ituiutaba - MG. Revista Pegada Eletrônica (Online). , v.17, p.143-172 - 172, 2016.

NOVAES, J. R. P. Trabalho nos canaviais os jovens entre a enxada e o facão. Ruris. Campinas, vol.03, n.1, p.105-127. 2009. Disponível em:

<http://www.ifch.unicamp.br/ceres/ruris-3-1-trabalho_nos_canaviais.pdf>, acesso em março de 2020.

PALHARES, I. Jornada de trabalho e esforço físico aumentam no campo. Folha de São Paulo, São Paulo, Caderno Cotidiano - Ribeirão Preto. Recuperada em 30 de maio, 2014, de <http://www1.folha.uol.com>.

PEREIRA, M. F. V. A migração para o trabalho no setor sucroenergético: situações nas "cidades da cana" no Triângulo Mineiro. In: XXIII ENCONTRO NACIONAL DE GEOGRAFIA AGRÁRIA. (Anais). São Cristóvão/SE: UFSE, s/p., 2016.

ROSA, L. A.; NAVARRO, Vera Lucia. Trabalho e trabalhadores dos canaviais: perfil dos cortadores de cana da região de Ribeirão Preto (SP). Cadernos de Psicologia Social do Trabalho, São Paulo, v. 17, n. 1, p.141-160, 12 mar. 2014. Universidade de São Paulo.

SANTOS, J. C; MATOS, P. F. Nas trilhas da Cana. 13 de fev. de 2014. 32min26s. Disponível em <https://www.youtube.com/watch?v=UX3Pw5F5TMM\&t=23s > Acessando em: 25 de jan 2021.

SILVA, M. A.M. Errantes do Fim do Século. São Paulo: Ed. da UNESP, 1999.

SILVA, Maria Aparecida de Moraes. Trabalho e trabalhadores na região do "Mar de Cana e do Rio de Álcool”. In J. R. Novaes \& F. J. 2007. 
SILVA, M. A. M.; MENEZES, M. A. Migrações rurais no Brasil: velhas e novas questões. [S.1.: s.n.], 2006. mimeo.

THOMAZ JÚNIOR, A. O agrohidronegócio no Centro das Disputas Territoriais e de Classe no Brasil do Século XXI. Campo - Território, v. 5, p. 92-122, 2010.

VERÇOZA, L. V. de; SILVA, M. A. de M. A resistência dos trabalhadores nos canaviais alagoanos. Agrária, São Paulo, v. 13, p.137-168, 2012.

Recebido em 06/04/2020.

Aceito para publicação em 22/12/2020. 